\title{
Young People's Engagement of Social Media for Social Transformation: Study of Nigerian University Students
}

\section{Chikezie Emmanuel Uzuegbunam, Nnamdi Azikiwe University, NIGERIA}

\begin{abstract}
This study using a sample size of 400 for survey and 12 focus group participants drawn from the population of a federal University in Nigeria, investigates the practicality of thinking about social media as online public sphere that offers Nigerian youth opportunity for such meaningful civic engagement and agenda setting. It investigates the level of access and social media literacy inherent in these youth, the uses they make of it, the extent of exposure and use and whether these translate into a culture of social transformation among these youth. Using the Uses-and-gratifications and public sphere theories, the study combined the use of survey and focus group discussions. The study finds that the level of awareness, exposure and use of Facebook among these youth is quite high. It is however found that the youth tend to make more personal, trivial and entertaining use of Facebook. The youth's social media usage thus disengages rather than makes for active engagement with their expected role in social transformation and development. The youth, with reasons, have never used Facebook or indeed any other social media to advocate or win support for a cause geared towards social change or social development of the society. It is concluded that Nigerian youth should be challenged to embrace serious online activism through the positive, prudent, informed, literate, and better appropriated use of the social media as both a socialisation and an empowering tool.
\end{abstract}




\section{Introduction}

"By the year 2015, there will be 3 billion people under the age of 25...They are the future...they are also the now".

James D. Wolfensohn (Former President of the World Bank, 2003).

It is no longer in doubt that the youth of any society, going by their growing population, are very critical to its existence and survival. They are judged as the future of that society. Little wonder then that they oftentimes are associated with being the colloquial "leaders of tomorrow". United Nations (2011) has reported that nearly 50\% of the developing world population is youth and children and there are 1.2 billion 15 to 24 year olds in the world and one billion of these live in developing countries. This "youth bulge" has clearly demonstrated that young people constitute not just a high and peaking segment of many populations across the world, but especially in Africa.

In Nigeria, the population of the youth is estimated at being about $65 \%$ of the overall 165 million citizens (Amadi, 2012, p.3). This figure is the largest alongside that of women (49 percent) (British Council, Nigeria 2012). For a country that boasts of such population of youth, it should not be a happenstance to think of the youth as having a pivotal stake in national development. The concept of youth engagement is increasingly apparent in international and national agendas, marking a shift in thinking about young people as resources that benefit society as well as key partners in development (Policy Forum, 2012, p.1). Sadly though, the country has over the past decade been negotiating unfortunate bends in terms of insecurity of lives and property, crime, terrorism, vandalisation of oil pipelines, militarism, political thuggery, all sorts of educational fraud and other social vices. The more worrisome fact is that the Nigerian youth have often been fingered as being instrumental to most of these challenges facing the country. They are a large and steadily growing population who undergo changes and also influence changes as the society itself keeps transforming. Thus, youth demographics and their desire for broad social changes can no longer be wished away.

The media remain one of the most powerful avenues for helping people and minorities contribute to social transformation, at least ones that concern them. Hitherto, the mainstream media seem not to have been successful in evolving any new and ready platform that encourage youth to participate much in development and social transformation. However, with the arrival of the new media and the growing ubiquity and widespread use of these technologies, and social media, various scholars have pointed to the hope, opportunity and platform which the new social media offers the youth the world over [Dhaha \& Igale, 2013, Chan-Meeto \& Rathackaren, 2010, Al-Jenaibi, 2011, Adaja \& Ayodele, 2013, Steinfeld, Ellison \& Lampe, 2008, Ufuophu-biri, 2013].

Indeed, the Internet has become the most essential medium for youth across most countries (see My Media Generation, 2005). Particularly, as Nigerian youths are seizing the new technology of the Internet to satisfy core needs, it's not too surprising that their perceptions of so-called mainstream traditional media are evolving fast (Omenugha, Ndolo \& Uzuegbunam, 2012; Obijiofor, 2009). Today, critical studies scholars view youth culture as a creative, contested, and complex process of social reproduction involving the youth of societies. Youth thus are seen as actively shaping society through strategies and means that are purely peculiar to them. For the Nigerian youth, these strategies could be the invention of new forms of language; creative contributions through popular culture (music, movies, fashion, etc.); 
reconstitution of political movements through participation in armed rebellion (kidnapping and the Boko Haram insurgencies); non-violent demonstrations and the reshaping of public discourse through social media and expressive culture, among others. The case of the "Arab Spring" which focuses on the power of social media in upturning regimes in Tunisia, Egypt and Libya and other places such as in Moldova and Turkey, is a good case in point here. As Safranek (2012, p.1) would share:

In the spring of 2011, the world watched as revolutionary fervor swept the Middle East, from Tunisia, to Egypt, to Syria and beyond. Startling images captured by civilians on the scene were viewed by people around the world, courtesy of distribution via Facebook, Twitter, YouTube, and even mainstream media. There can be no doubt that information and communication technologies, in particular burgeoning social media, played a part in the upheavals.

With youth at the forefront of such revolutionary public protest that have led to regime changes in these places, it is becoming clear that through activism sparked by this generation's increasingly interconnectedness brought by social media and technology, these youth, like many of their contemporaries in other parts of Africa and the world, are responding to the reality of social issues such as low wages, high unemployment, poor governance and other factors that threaten to stifle their future .

The use of social media such as Facebook, YouTube, Twitter, Blogs and others as a new means to disseminate messages and engage the audience in participatory communication has created a new dimension in social mobilization making it easier to organize and disseminate ideas. It has been suggested that using social media tools in recent times, has become an effective way to expand reach, foster engagement and increase access to credible messages on issues of development (Dunu \& Uzochukwu, 2011). Other scholars agree that social media, especially social networking sites (SNS), enable users to present themselves, establish and maintain social connections with others, and articulate their own social networks (Ellison, Steinfield \& Lampe, 2007, Weinberg, 2009; Kaplan and Haenlein, 2010; Meerman Scott, 2010). The one significant thing about the social media is the fact that it:

[Expands] the extent to which once-passive audiences are able to engage with media producers and fellow consumers. This is commonly linked to a "democratisation" of the media: the expanded interaction of members of the community through the media, and the ability of user communities to have greater editorial roles in shaping the content they consume, and recommend to peers in their social networks. (Chen \& Vromen, 2012, p.1)

To advance the foregoing argument, Facebook, among other social media and social networking sites, has grown exponentially over time to become the biggest and most popular social networking site today with online population of above I billion active users, as at the end of 2012 (Facebook, 2012b), and still counting. Its introduction has become one of the most important social trends of the past decade. Available in over 70 languages, Facebook sure has become a global phenomenon and experience. This singular social media according to Marichal (2012) has been useful site for micro-activism and the formation of alternative spaces - or counter publics - for democratic discussion (Dahlberg, 2011). However though, scholars bemoan the apparent decline in the rate of youth civic engagement even on the Internet (Putnam, 2000; $\mathrm{Wu}, 2009$ ). Online civic engagement here means the active 
participation of young people in their community - in government, in decision-making, in development etc., using social media as empowering tools.

It is thus argued that youth are conveniently disengaged from the more serious matters such as politics, much more than their older counterparts; and this invariably could explain the kind of uses they would make of Facebook and indeed other social media. Still, borrowing from the monumental Arab Spring revolution spurred by Facebook social media, CostanzaChock (2012, p.4) argues that young people, especially immigrant youth, are often directly connected to social movements in other parts of the world, and are inspired by movements that they encounter via social media or television. How and to what extent this statement rings true for Nigerian youth as they negotiate the social and national transformation bend, however remain questionable and a subject of serious enquiry.

\section{Research Questions}

The following research questions were investigated:

1. To what extent do youth have access or are exposed to the social media, Facebook?

2. What are the predominant uses which youth make of Facebook?

3. To what extent do youth use Facebook to engender a culture of social transformation?

\section{Delimitation of the Study}

Social media generally comprise mainly of Facebook, Twitter, YouTube and blogs. Nevertheless, this study has its scope on Facebook, being the most popular and exponentially growing social media among young people both in Nigeria and elsewhere. Similarly, the study is delimited to the undergraduate students of Nnamdi Azikiwe University, a federal university in the eastern part of Nigeria.

\section{A Discourse on Youth Engagement, Social Media and Social Transformation}

The term youth refers to persons whose identity lies between being children and being adults. In a strictly legal sense, the term is typically applied to persons from the time of their early teens until a point between the age of 16 and 21, after which time the person is legally an adult (Heaven and Tubridy, 2007). Used colloquially, however, the term generally refers to a broader, more ambiguous, field of reference - from the physically adolescent to those in their late 20s. The United Nations, for example, defines youth as people between the ages of 15 and 24 years inclusive (United Nations, 2011). This goes to show the difficulty in explicitly defining the term. Large (2005) quoted in Ahn (2011) suggested that defining such social categories such as adolescents, children, and young adults in concrete terms is always problematic in research, due to the fact that they are socio-culturally constructed entities. And so, traversing both sides of the legal distinction between childhood and adulthood, the youth identity presents those in their teens and their 20s as participants in a shared social experience that is dissimilar from that of other age or cultural groups. However, for our discussion of young people, this study chooses to place its definition of youth as young people between the ages of 18 and 25. Ordinarily and ideally, youth when viewed in terms of their role in constituting a force for social change for themselves and society, should be actively involved in any development process. The rights of young people even in Nigeria, in this regard is unequivocal. Youth engagement is synonymous with youth participation. Meaningful youth participation involves a genuine opportunity for young people to influence decision making and bring about change. This obviously equates to a shift of power. Participation is a commonly used approach and concept within development discourses. Through active participation, young people are empowered to play a vital role in their own development as 
well as in that of their communities. The United Nations has long recognized that young people are a major human resource for development and key agents for social change, economic growth and technological innovation (United Nations, 2011).

The coming of the new [social] media on the communication scene opened up the third phase of the Internet revolution consisting of email/computer systems and the arrival of the Web. Social media thus is still the newest and most celebrated communication and technological innovation today. Juxtaposed with the more conventional mainstream media, the social media tools offering new and powerful ways to communicate, share and create information, collaboratively and more creatively, is different in a number of significant ways; marking a change from a unidirectional to a multidirectional model of communication. Control of information has been ceded to the users themselves, meaning that social media users have become both users and producers of media. Bruns (2009, p.3) quoted in Evers, Albury, Byron \& Crawford (2013) has called them 'produsers'. And so, user generated content is the mainstay, as most social media sites have no editors. This has made every social media user both a publisher and a critic of information.

Social media, write Mayfield (2008) and Abubakar (2011, p. 447) is online or electronic media which have the capacity to facilitate participation, openness, conversation, community, connectedness and at the same time, foster textual and audio-visual characteristic appeal amongst online users. The core of social media as explained by Trusov et al. (2009) lies in the fact that users can have individual profiles and personal images; users are able to communicate their thoughts, feelings, interests (music, hobbies, preferences) and link to affiliated profiles (friends or professional fan pages). Furthermore, it is one of the new media networks which provides users with the mix of interpersonal and mass communication capabilities that have not existed before, and which place emphasis on interactivity and mobility (Paxson, 2010, quoted in Adaja and Ayodele, 2013).

\section{A Look at Social Media (Facebook)}

Various social media applications exist that allow the creation, modification and exchange of online content. Globally, Facebook as the most popular social networking site has grown exponentially in name and in use. It has continued to arguably change the world of communication, online connectivity and information sharing and access. Writing about this significance, Time magazine quoted in Fletcher (2010, p.22) reported that: Sometime in the next few weeks, Facebook will officially log its 500 millionth active citizen. If the website were granted terra firma, it would be the world's third largest country by population, twothirds bigger than the U.S. More than 1 in 4 people who browse the Internet not only have a Facebook account but have returned to the site within the past 30 days.

Today of course, statistics show that Facebook has successfully logged over I billion users and still counting. The remarkable thing is that as the population of Facebook users continues to grow even more than the size of most countries of the world, these users are becoming online citizens of sorts. These have been metaphorically termed "netizens" (Hauben \& Hauben, 1997). The manner in which Facebook has continued to grow and its global reach perhaps symbolizes that we have entered the era of what Barry Wellman and Caroline Haythornthwaite (2002) have called the "networked individual" - an individual who has become highly online-connected and is used to create ties and networks with other people. This corroborates with what boyd and Elison (2007) said that what makes social network 
sites like Facebook unique is "not that they allow individuals to meet strangers, but rather that they enable users to articulate and make visible their social networks".

This process of articulating and making users' social networks visible perhaps involves young people [as one of the significant users or citizens] being 'active' online.

\section{Nigeria, Young People, Online (Social Media) and Social Change}

Facebook and Twitter rank among the most popular social networking sites in Nigeria and indeed Africa. The Internet World Statistics reports that there are 48,366,179 Internet users in Nigeria, as at June 30 2012, i.e. 28.4\% of the population, and over 11 million Facebook users as at December 31, 2013 according to CP-Africa; thus making Nigeria Facebook's largest user base in Sub-Saharan Africa. Meanwhile, Asuni \& Farris (2011, p.4) has also reported that 87 million Nigerians own mobile phones that can send and receive SMS messages and that 60,000 Nigerians are on Twitter. In Nigeria, young people appear to be increasingly seen to be part of the online activism that has brought about considerable amount of social transformation or social change. This is seen in the trend of activism generated especially during crises or critical times in the political life of the nation. Visit blogs and news sites and the social networks and you would be met with stark criticism and agitations calling for attention. By social transformation, I mean a large scale social change occurring in an individual's life or externally, in the social system. It also means in this context, any changes in the existing parameters of a societal system, including technological, economic, political and cultural restructuring.

Broadly speaking, Nwonwu (2011) enthuse that while the rest of the world was still paying heed to the use of new media innovations as a tool for furthering interpersonal relationships in the office, classroom or community at large, youths in Africa have come to see them as an invariable tool in the furtherance of the quest for freedom, justice and a better, well administered society. Perhaps this might be because such things as freedom, justice and order are much-needed in the continent.

The level of activism experienced first during the 2011 General elections in Nigeria opened up a unique platform for debate and discussion on Facebook social media which was not privileged by the mainstream media. This perhaps was the motivation for Goodluck Jonathan's presence on Facebook. Again, its use during the fuel subsidy saga remains pivotal to this discussion. When on New Year's Day, January 1 2011, the Federal Government of Nigeria announced the decision to implement full withdrawal of petrol subsidies, the decision was met with a backlash as enormous as expected. For the couple of weeks that followed, the mainstream media, the social media and public discussions were awash with the fuel subsidy imbroglio and all the politics and economics surrounding it. However as Nigerians waited for the official authorities, the usual opposition group - the organised Labour group - to take action, a new force emerged. This time, it was engineered by young people via the social media, using tools that they were at home with - Facebook, BBM, Twitter, blogs, etc. These were used to share pictures of the adverse effects of the skyrocketed petrol prices in various parts of the country, opinions and relevant information and updates regarding the crises. The level of activism inspired by these young people also led about 1 million Nigerian youth to sign an e-petition against the fuel subsidy issue [See http://myspur.com.ng/index.php?do=/petition/1/1-000-000-youth-sign-against-complete removal-of-fuel-subsidy/]. Inspired by the Occupy movements of America and Europe, the 
online movement was christened the Occupy Nigeria Movement. Amaza (2012) puts it more succinctly:

...the Occupy Nigeria movement was like them, a leaderless movement. You could not point to a specific person and say that he or she was the top leader. It was just composed of individuals who had long bottled up their anger and frustration with the state of affairs in the country. They used social media to organize themselves, bridged ethnic and religious divides in a way like never imagined and braved the odds to even stage sit-ins that lasted the whole cold harmattan nights. They also broadened the struggle from being about just fuel prices to being about the size and cost of the government to corruption. One characteristic of the Occupy Nigeria movement was within the larger movement, there were different opinion groups and smaller movements especially with regards to what was the best approach to solving the fuel subsidy crisis...

Here, we could see how Nigerian youth were able to use social media to form strong ties that culminated in the 'movement' that saw the government reverting back the pump price of petroleum products in Nigeria to at least a manageable minimum and de-exacerbated the crisis. Further, another incident in Nigeria which has indeed illustrated how active Nigerian youth can be was the killing of the four UNIPORT students. This happened at the last quarter of 2012. The pictures and videos of the barbaric killing of the youths who were alleged by the villagers to be robbers, in a remote Aluu settlement in Rivers State by unwholesome native miscreants, went viral on the social media. Eye witnesses of the account, especially young people using their Blackberry and other smart phones, got Nigerians aware of the incident that generated heat for a long time. The fact that the victims were young people also gave electricity and popularity to the discourse, as more and more aggrieved youth used the social media platforms to vent their disapproval. This had a ripple effect of stimulating the sympathy and condemnation of the act by other Nigerians. Eventually, the government and the civil authorities had to wage in and conduct investigations that saw some people connected with the gruesome killings being brought to book.

The growing power of new media as a tool for social change in Africa was again exemplified in September 2012, when a story that was initially carried by at least one national newspaper a month before and largely ignored, was picked up by popular Nigerian blogger, Ms Linda Ikeji and thrust into national and international prominence, forcing the government to alter its usual approach to issues that concern the citizenry. Attempts to sweep the issue, which involved the gang rape of a teenage girl by youths who videoed and circulated the event, were rebuffed by majority of Nigeria's growing army of internet savvy youths, who kept highlighting the issue, vowing to keep at it until the case is resolved and the perpetrators are in jail. Unlike what holds in Nigeria, where several high profile cases in the past have been left unsolved, the efforts of citizen investigators working through the internet, as of the time of writing, led to some arrests and alleged identification of the victim. There was also the case of the Nigerian ambassador to Kenya, whose career was brought to a sudden closure some months earlier, largely due to the flurry of condemnation that followed the publication of a story of alleged wife battery by a Kenyan newspaper. Though the Kenyan newspaper that ran the story lacked the capacity to give the story much coverage, a single posting of the story to a site favoured by young Nigerians was enough to grant it the massive exposure that caused the usually unreachable Nigerian diplomatic community to issue statements and for the Nigerian President to recall the ambassador. Or what do we say of the amount of youth backlash on social media against the Federal government and the Academic Staff Union of 
Universities (ASUU) during the recent six-month old strike action by university lecturers that halted the academic life of Nigerian students? More recently also, in the tail end of the year 2013, Governor Adams Oshiomhole of Edo State was in the eye of the storm over his careless and disdainful treatment of a widow in Benin, the state capital, where he sits as Governor. Oshiomhole was supervising an environmental cleaning exercise, and there, at the roadside on Mission Road, was one Mrs Joy Ifijeh, with her goods displayed for sale. The governor ordered that her wares be removed, and when the woman tearfully pleaded that she was a widow, Oshiomhole would have none of it. In an obvious fit of anger, he spoke some very harsh words, and asked the woman to "go and die," if she wanted. For this action which many Nigerians, young and old, described as inhumane and undeserving of a leader, the Edo State governor received a lot of criticism and or condemnation, particularly from the online media community (Social network sites, blogs and news media sites). He was called all sorts of names, from wicked to dictatorial, arrogant and overbearing. In a quick move to salvage his image which was at a critical point, following the counterattack from the online community, the governor invited the woman over to the State House, apologised, dined with her and gave her a job with the War Against Indiscipline squad, and the sum of N2 million. He also promised to see her son through university whenever he gained admission. Meanwhile, the People's Democratic Party (PDP) also cashed in on the opportunity and also offered the widow the sum of N250, 000. The point to note in all this is that hitherto, injustices and neglect such as this could have taken place and no one gets to hear about them, but not in today's world of the Internet, social media networks, smart mobile phones and growing online communities.

\section{Theoretical Framework}

Two theories have been found suitable to anchor this present study on. They are the Usesand-gratification theory of Mass Communication and the Public sphere theory.

The Uses-and-Gratifications theory: Earlier research on the Uses-and-gratifications theory focused on audience motives for selecting traditional media sources and the gratifications they obtained from them. However, as the new media technologies evolved, attention began shifting on these technologies and how Uses-and-gratifications approach could be applied to them, hence further strengthening the theory as it relates to our understanding of mass communication. From the empirical literature review attempted above, very many scholars from various parts of the world have sufficiently used this theory to study how young people especially, use the social media. Thus, this approach is one of the most cited communication theories as best tool for analyzing new media technologies (Ebersole, 2000).

With the increasing adoption of social media, for this present study, the Uses-andgratifications approach seems promising in providing a theoretical framework from which to examine Nigerian undergraduate students and their Facebook use - firstly, the actual and predominant uses and gratifications sought and obtained from the use of Facebook, and ultimately to investigate the extent to which they put Facebook to engineering social transformation and change in their societies.

The public sphere theory: The public sphere theory originated from a second-generation German sociologist, political scientist and critical theorist, Jurgen Habermas who emerged in Europe around $18^{\text {th }}$ century from the social enquiries of Frankfurt School. It was an offshoot from his seminal work in a monograph titled The Structural Transformation of Public Sphere (1962), in which he viewed public sphere as various avenues where citizens can freely 
express, participate, communicate and share their understanding, ideas and information that involve political, social issues and other diverse things that affect their social coexistence (Abubakar, 2012). Traditionally, earliest notions of the public sphere comprise of public spaces such as clubs, coffee joints and saloon joints, assemblies and hangouts and in Nigeria, motor parks, viewing centers, tea joints, market places and indeed any other public forums that has the potentiality to bring people together on common grounds to debate about issues. With the advancement in information and communication technology and society at large, the basic tenets of the Habermas' public sphere have also been advanced from an easily physical, locational stage to a more sophisticated, online-based but complicated communication space where concerned members of the society could gather, in a virtual world and "exchange opinions regarding public affairs" and deliberate sometimes in a critical and analytical manner ((Abubakar, 2012; Allan, 2010, p.10; Ubayasiri, 2007, p.2). For the present study, this theory becomes very pertinent in helping to gauge the practicality of assuming that social media can be used as a public space by young people to engender a culture of social transformation and change in their societies.

\section{Methodology}

This study is designed as both quantitative and qualitative. In other words, it privileged triangulation - combining the use of survey and focus group discussion. For the survey, a sample of 395 undergraduate students was drawn from the population of study totaling about 36, 000 students from Nnamdi Azikiwe University, Awka, a Federal University in Nigeria. This was done using the formula worked out by Taro Yamane, for determining study sample sizes. Analyses were computer-assisted using the Statistical Package for the Social Sciences (SPSS). Data were presented in statistical tables and percentages. The research objectives were tackled by interpreting the statistical relationships among the relevant variables.

For the focus group discussion, two separate group discussions were held. Each comprises of six undergraduate students aged between 18-25 years, drawn from different departments of the University. The choice of six participants each is based on Liamputtong's (2010) assertion that FDGs "involve a group of 6-8 people who come from similar social and cultural backgrounds or who have similar experiences or concerns". The discussion/interview was transcribed into full text and the contents thematically analysed, albeit in direct comparison with the quantitative data. 


\section{Data Presentation and Analyses}

I. Use of Social Media: Facebook

Figure 1: Social media respondents make the most use of.

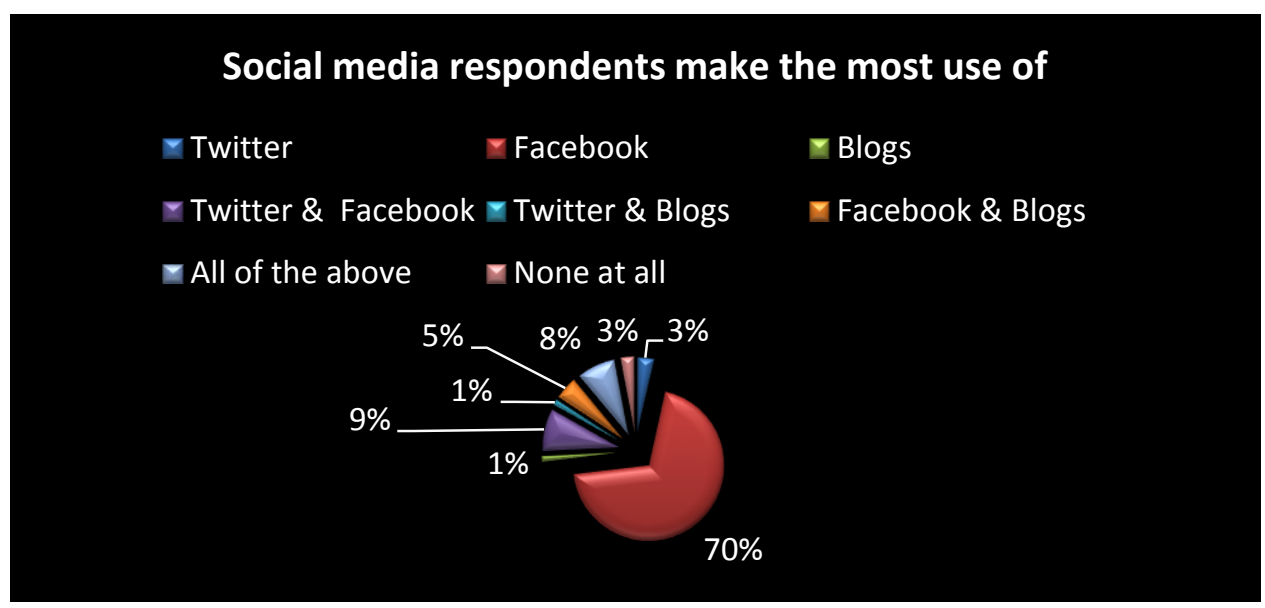

Table 2: showing data on the respondents' use of social media, Facebook

\begin{tabular}{|c|c|c|c|}
\hline Variable & Category & Frequency & Percentage \\
\hline $\begin{array}{l}\text { Respondents with } \\
\text { Facebook } \\
\text { Presence }\end{array}$ & $\begin{array}{l}\text { No } \\
\text { Yes }\end{array}$ & $\begin{array}{l}10 \\
335\end{array}$ & $\begin{array}{l}2.9 \% \\
97.1 \%\end{array}$ \\
\hline $\begin{array}{l}\text { How long since being } \\
\text { on Facebook }\end{array}$ & $\begin{array}{l}\text { Less than a year } \\
1-3 \text { years } \\
4-6 \text { years } \\
7-9 \text { years } \\
\end{array}$ & $\begin{array}{l}44 \\
169 \\
122 \\
20 \\
\end{array}$ & $\begin{array}{l}12.4 \% \\
47.6 \% \\
34.4 \% \\
5.6 \% \\
\end{array}$ \\
\hline $\begin{array}{l}\text { Frequency of visit to } \\
\text { Facebook }\end{array}$ & $\begin{array}{l}\text { Everyday } \\
\text { Once a week } \\
\text { Several times in a } \\
\text { week } \\
\text { Once a month } \\
\text { Once in a while }\end{array}$ & $\begin{array}{l}129 \\
22 \\
102 \\
10 \\
95\end{array}$ & $\begin{array}{l}36 \% \\
6.1 \% \\
28.5 \% \\
2.8 \% \\
26.5 \%\end{array}$ \\
\hline $\begin{array}{l}\text { How much time } \\
\text { spent 'Facebooking' }\end{array}$ & $\begin{array}{l}\text { Average of 1-2hrs } \\
\text { Average of 3-5hrs } \\
\text { Less than 1hour } \\
\text { Others }\end{array}$ & $\begin{array}{l}140 \\
26 \\
175 \\
10\end{array}$ & $\begin{array}{l}39.9 \% \\
7.4 \% \\
49.9 \% \\
2.8 \%\end{array}$ \\
\hline $\begin{array}{l}\text { Medium used to } \\
\text { access Facebook }\end{array}$ & $\begin{array}{l}\text { Mobile phones } \\
\text { Personal computer } \\
\text { Cybercafé } \\
\text { A \& B above } \\
\text { A \& C above } \\
\text { B \& C above }\end{array}$ & $\begin{array}{l}242 \\
22 \\
4 \\
76 \\
12 \\
2\end{array}$ & $\begin{array}{l}67.6 \% \\
6.1 \% \\
1.1 \% \\
21.2 \% \\
3.4 \% \\
0.6 \%\end{array}$ \\
\hline $\begin{array}{l}\text { Based on observation, } \\
\text { what respondents, } \\
\text { friends do more on } \\
\text { Facebook }\end{array}$ & $\begin{array}{l}\text { Reading friends' } \\
\text { comments/messages } \\
\text { Uploading } \\
\text { photos/personal } \\
\text { thoughts }\end{array}$ & $\begin{array}{l}45 \\
89 \\
111\end{array}$ & $\begin{array}{r}13.3 \% \\
26.3 \% \\
32.7 \%\end{array}$ \\
\hline
\end{tabular}




\begin{tabular}{|c|c|c|c|}
\hline & $\begin{array}{l}\text { Chatting } \\
\text { Reading updates } \\
\text { from friends } \\
\begin{array}{l}\text { Engaging friends in } \\
\text { discussions via } \\
\text { posts }\end{array} \\
\text { Making new friends } \\
\text { All of the above }\end{array}$ & $\begin{array}{l}32 \\
40 \\
10 \\
12\end{array}$ & $\begin{array}{l}9.4 \% \\
11.8 \% \\
2.9 \% \\
3.5 \%\end{array}$ \\
\hline $\begin{array}{l}\text { Kind of content } \\
\text { respondents usually upload }\end{array}$ & $\begin{array}{l}\text { News } \\
\text { Entertainment stuff } \\
\text { Religious stuff } \\
\text { Political stuff } \\
\text { Shared contents } \\
\text { On serious societal } \\
\text { issues } \\
\text { All of the above } \\
\text { Others }\end{array}$ & $\begin{array}{l}37 \\
86 \\
49 \\
10 \\
32 \\
64 \\
13 \\
25\end{array}$ & $\begin{array}{l}11.7 \% \\
27.2 \% \\
15.5 \% \\
3.2 \% \\
10.1 \% \\
20.3 \% \\
4.1 \% \\
7.9 \%\end{array}$ \\
\hline
\end{tabular}

Figure 2: What respondents spend more time doing on Facebook

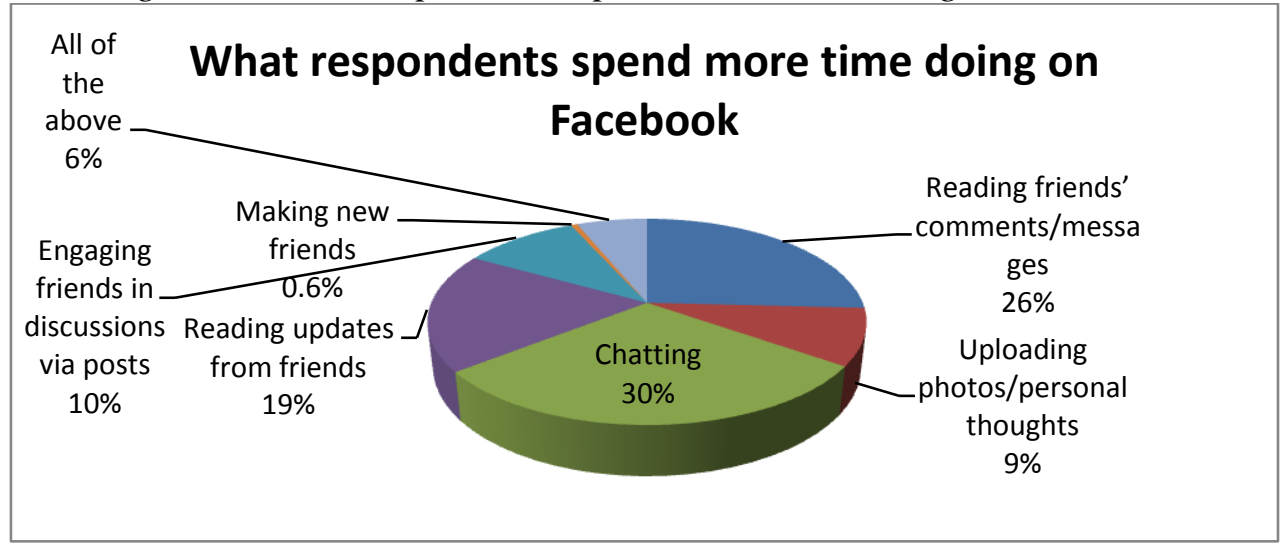

Unlike in the survey, participants in the focus group interview were asked to say, in their own words, what 'Social media' means to them as young people. What came out from their responses is that these young people have a considerable knowledge of what it is all about. Majority see it mainly as opinion media as well as an interactive media. Thus, their answers include definitions such as: " it is kind of an opinion media where people merely air their own personal views about particular things"; "a place to meet people and share information and seek the opinions of others"; "a platform where you can express your thoughts about the things that are bothering you"; "has to do with interaction"; "is synonymous with young people because they are trend-setters"; "an interactive platform... that helps to foster usergenerated content, with characteristics of interactivity and participation" etc. One of the youths in the discussion gave a rather robust definition of social media thus: 
I see social media as a social arm that links people all around the world; a place where you can get in contact with people that you have never seen; and of course it is very seamless and anonymous, meaning you can say anything. It is just like when we talk about the democratic experimentation, freedom of access to communication and the media - that's just what social media is about: to give everybody a voice where all of us can have a stake. If I feel anything now, in fact before I even think about a thing, am already typing away because it is a way of expression. It is way of thinking... It gives me that idea that I can actually say something and anybody can know what am thinking right now; that yes, am somebody and people will be there to listen to what I have to say and comment on it, people I don't even know, even foreigners. You feel like you belong to the global system somehow. Even though you may not have money, you may just be in your corner in your village but you have a voice... (Focus group discussion, 20 July 2013).

It is remarkable to note that the young people's ideas about social media emanate strongly from the uses they and their friends make of it. Another thing that came out from this social media question is the fact that many of the participants agree that social media has become "a combination of the print media, broadcast media, public relations and advertising joined together online and it makes it faster". They again maintain that social media is a kind of media that has come to give people the opportunity to participate, unlike what obtains in the traditional media paradigm. According to them, unlike the traditional media, SM give people room to give feedback and to be co-creators of media content. One of them said "we see things portrayed as news in the traditional media, but they are rarely discussed there. It is now on this social media that they are actually discussed by people". The direct implication of this trend has called for yet another common trend today: "That is why you see newspapers having online Facebook accounts. They now have social media accounts because they know that is the source of the interaction purpose of every media".

From quantitative data above, Facebook ranks as the social media that majority of the respondents (67 percent) make the most use of. Also, 97.1 percent of the survey respondents aver to having Facebook accounts. This finding is sustained in the focus group discussion, as the participants unanimously agreed that Facebook is their most preferred and most used of all the social media, which ranges from Facebook, YouTube, Twitter, Blogs, Wiki, Instagram, Badoo, to mention a few. This claim is further substantiated with various reasons given by the participants: "Because it is where you make new friends and are updated on so many things"; "It helps me to lighten up especially when am bored"; "Because I get to discuss with my friends in their various locations scattered all over, get information from them and use those information to adapt to where I am"; "Because it has this multi-media approach - it has a section for chatting, a section to upload and share things and a section to air your views"; "It helps in spreading information between friends and others, faster"; "Because it is a place you can meet influential people and learn from them", and so on.... The participants all agreed that Facebook is not just a user friendly medium; it is, according to them, "a multi-purpose media", where hard-core news and current information could be found, where entertainment abound, where educating pieces are at reach, and where one can get personal, such as letting the world know how/what you feel at any moment and interact with friends. They however observe that the ability of a Facebook user to utilise all these effectively largely depend on "how many friends you have, how many pages you LIKE, how many groups you belong to and the kind of pages you like as well". 
The youth engaged in the discussion were also found to be Facebooking "everyday", "on daily basis", and "all the time", falling in line with the results from the survey where respondents who facebook every day and several times in a week are 65 percent. Since Facebook is adjudged the most preferred and used social media, it is worthy of note to state that Facebook use is found to be highly prevalent in the lives of the young people I engaged in the focus group interview. Most of them consider it a 'hide-out' where they go to meet their friends whenever they are physically bored stiff or in need of diversion. It was commonplace then to hear some of the participants saying that "Facebook is a place where I go to when I don't have any other place to go to. Sometimes it's kind of a defense mechanism for me when I feel awful or something; I just go there to say anything I feel". Another participant, who had been tagged "Facebook" by his family as a result of his constant Facebooking habit, has this to say:

Most of the time, due to the fact that I facebook often, my mum and my siblings call me "Facebook". Yes, they name me facebook because at a point when they wake up around 8 am before they go to work they will be like "Mike [not real name], have you heard? Did you hear that maybe the President said this or did you hear this and that about the ASUU strike?" I will tell them "see I've read all these things online before you guys woke up, so I already know them" And they will be like "Wow, okay". So they will say this is one of the benefits I derive from Facebook. (Focus group discussion, 20 July 2013).

Further revelations from the focus group interviews also hinted that adolescents are also found to be making heavy use of Facebook. The participants recounted how their $12-14$ year old siblings and neighbours are making heavy and disturbing use of Facebook. This degree of the participants' Facebook use is further exemplified in how long they have been registered Facebook users and the number of friends they have. They, like the 82 percent in the survey that claim they have been on Facebook for the past $1-6$ years, have been active Facebook users between 2004 - 2010, just as the number of their Facebook friends ranged between $150-1,500$. The participants were divided among those who believe they should not have many friends and so, should censor their friends; and those who simply add anyone that requests their friendship and in turn requests anyone they "thought looked cool and everything". Moreover, some of the participants admitted to having two or more Facebook accounts, bearing different names and sometimes even pseudo-names. They were however hesitant to say the real reason(s) why they do this. One of the participants who personally find the act distasteful offered a possible answer:

It means the person has a vice stocked inside of the person. It's becoming rampant nowadays; you know. You just give yourself another name that doesn't exist in order for you to express the other side of you. It means you have an animalistic tendency (Focus group discussion, 20 July 2013).

On a cumulative scale, almost 90 percent of the respondents in the survey spend between [less than 1 hour] - 2 hours facebooking. This finding is in line with that emanating from the focus group discussion where the participants spend between 5 minutes - 3 hours facebooking whenever they are logged on. This finding presents a somewhat undecided position on the issue of how long young people stay online facebooking. This is because a good number of the respondents still allege that they stay as long as they are interested while some say they stay for 24 hours. It was found that this is seen among those of them who have Blackberry or Android phones. With such smart phones, they "can stay online for even one 
week; that means [I] can always appear online to people and my status will be showing am online for one week". Another said "some of us use Blackberry phones and we get notifications alerts every second. But sometimes, it doesn't mean you are active, like making use of it, even though you are receiving the notifications from Facebook".

It came as no surprise that mobile phones are the predominant, most preferred and readilyavailable medium used by participants to facebook. One of them quipped "when I am with my phone, am always online because anywhere I am, even in class sometimes, I am tempted to know what's happening in the online world".

Already, in the survey, 67.6 percent of the respondents declare that mobile phone is their main medium of accessing their Facebook accounts. The focus group discussions afforded the opportunity to elicit from the participants the reason why this is so. According to them, "it's an easy way to facebook, it goes everywhere with you"; "it is very portable"; "it has ease of access; you know, you could just play with it anytime"; "the cost is cheaper". On the contrary however, some participants pointed out the fact that using laptop or the computer system to facebook could be more gratifying in the sense that "things are larger in size with the computer system", "it's easier to use some Facebook applications and features when facebooking with your computer than with a phone" and "you can chat with someone else and at the same time scroll down and look at other people".

Still on the uses they make of Facebook, their responses on the particular activity(ies) that take(s) more of their time on Facebook, were in no way similar, unlike the data from the survey which suggested that 30 percent of them spend more time chatting and another 26 percent spend more time merely reading their friends' updates and comments.

What could however not be hidden from the whole discussion about the particular uses young people make of Facebook is the fact of the obvious frivolity inherent in these uses. One of the participants confessed off-guardedly:

There's also one thing am fond of doing: if I get dressed and about to go out, I snap pictures with my phone and post them with something like "Off to school; how do I look?" And you find out that more than 27 persons will comment and tell me "you look good, you look this, you look that...

Moderator: now do you get more comments for picture-posting than for your motivational and serious talks?

Speaker6: Yes it's different. If I share my motivational stuff, I can get like 7-8 comments but when I post an "Am off to school" picture for example, I might end up getting like 28 or more comments. Sometimes they even tell me to go and change to different attire that the one I was about going out with didn't fit. And I would do that; then snap and post again... Then everyone will just laugh and I will then be like "Bye guys, am off to school"... It's always as though I am seeing them and they are seeing me... (Focus group discussion, 20 July 2013).

If the youth from the survey and the participants of the focus group discussions agree that Facebook ranks as their most loved, used, and preferred social media, the question at this moment is: how much critical knowledge do they have about the Facebook? How literate are they about it? These questions become important because, commonsensically, the extent of 
one's use about something could be dependent on the extent of the person's knowledge and literacy about that same thing.

For this, 59.7 percent of the survey respondents affirm their awareness of other Facebook applications/features aside the most common ones like News feeds, Timeline, Wall, and Notifications. In furtherance of this finding, participants in the focus group discussions were asked to name, off-heartedly some of the Facebook features or tools aside the most common ones mentioned above. As a result, they named Facebook Chat, LIKE, SHARE, COMMENT, Facebook Notes, Facebook Pages, Facebook Group, Tags, Message Inbox and others as the Facebook tools and features they know. Their answers showed that they, to a very significant extent, are aware and knowledgeable about most Facebook features and or tools. However, survey data also suggest that a good number of the youth do not make use of some relevant Facebook tools such as Facebook Notes and Facebook Question. This could be as a result of low literacy about them.

The youth were brazen enough to equally say that they would equally advise such 'illiterate' persons about some dangers inherent in the way people tend to misuse the Facebook social media. These include the danger of being exposed to what they called "rubbish, pornographic and nude pictures"; identity falsification that are used for fraud, sex commercialization, sexual harassments, blackmails, extortion of money from online victims and all sorts of other nefarious acts. Most of them were also quick to mention the fact that Facebook could be quite addictive. One of the participants was rather conclusive: "I will simply tell her the truth: it is simply a distraction". When probed further on the issue of distraction, the youth concluded that Facebooking sometimes pose disturbing challenges to young people's academic growth by encroaching into their study times. These findings inevitably create a paradoxical feeling of whether to allude blessing to it or a curse, instead.

\section{USE OF FACEBOOK FOR SOCIAL CHANGE AND TRANSFORMATION}

\begin{tabular}{|l|l|l|l|}
\hline Variable & Category & Frequency & Percentage \\
\hline $\begin{array}{l}\text { Awareness of Arab } \\
\text { Spring revolution }\end{array}$ & No & 239 & $66.6 \%$ \\
\hline $\begin{array}{l}\text { Use of Facebook } \\
\text { to advocate or win } \\
\text { support for a cause } \\
\text { that brings social } \\
\text { change and } \\
\text { national transformation }\end{array}$ & Yes & 245 & $33.4 \%$ \\
\hline $\begin{array}{l}\text { Awareness of } \\
\text { group/organization on } \\
\text { Facebook which } \\
\text { champions using youth } \\
\text { for social change }\end{array}$ & Yes & 110 & $69 \%$ \\
\hline $\begin{array}{l}\text { Membership of } \\
\text { group/organization on } \\
\text { Facebook which } \\
\text { champions using youth } \\
\text { for social change }\end{array}$ & Yes & 152 & $31 \%$ \\
\hline
\end{tabular}


This section discusses the extent to which young people have been able to use the social media, Facebook in this instance, for any social change or social transformation in their societies. This was evaluated through a series of questions. Firstly, the participants in the focus group discussions were asked whether they are aware of the popular case of the "Arab Spring" where young people were part of the population that used social media to cause revolutions in Iran, Tunisia and Egypt in recent times. Almost all of them confessed to their only having heard about it from the grapevine but neither have an in-depth knowledge nor taken time themselves to look up/read up on the incidences. Their responses were no different from what one of them said "People have told me about it but I have not gone to check it out. Right now, I just made a note on my jotter to remind myself I have to go check this thing out..." Only a very few were able to recount at least a brief story of how the Tunisian revolution, for instance, began.

Meanwhile, 66.6 percent of the survey respondents have said they are not aware and knowledgeable about the Arab Spring revolution in these places. What however came out strongly from the focus group discussions was the fact that the respondents did not mince words in saying that social media, with the help of smart phones in vogue today, are giving even Nigerian youths opportunities to bring to the fore societal injustice and other issues and upheavals that could make Nigerians better informed, just as the young passer-by who got the video clip of Mohammed Bouazizi, the Tunisian who set himself on fire and caused the upheaval that led to the revolution, did. This goes to show that social media with the help of smart and digitally updated mobile phones are fast becoming avenues whereby even the very ordinary citizens could practice amateur or citizen journalism and bring to public glare some nefarious happenings in their immediate environment, just as is the case in Tunisia (via YouTube) and other places. According to them, even the attention of necessary authorities, are by the virtue of social media tensions and activisms, drawn to such social cases. In Nigeria, the youth in the discussion mentioned about three main incidences where young people used social media to air their grievances, namely: the period of the fuel subsidy removal, the killing of the four undergraduate students in Aluu settlement in Rivers State and the period of the prolonged ASUU strike action.

While 69 percent of those surveyed acknowledge they have never used Facebook to advocate or win support for a cause that will bring about social and national transformation, those engaged in the group interview with me also, without trying to impress me, agreed to having done little or nothing in this respect. But some of them who insist they do, reveal that the best and the littlest way they do so is to "to talk about it on [my] personal Facebook page", "commenting and contributing to conversations online", "dishing out information and letting people talk about it" and "stressing more on people's attitude, reading and sharing lots of motivational pieces too". On the other hand, there appears to be a major reason why the effort is reduced to this rather run-of-the-mill level. One of the participants was bold to have said:

I use more of words because the truth is that we are in a country that is not secure. That is why most of us are afraid that you don't know what you will upload and tomorrow they will start tracking you. You are all aware of what happened in USA when Mr. Snowden exposed the CIA. In America people's phone lines can be tracked. In such a location you don't know what and when to upload certain statements or pictures for the fear of the unknown. But even at that, they have security to protect the citizens. Mr. Snowden today is being protected by Russia and China. But in Nigeria today where are you going to hide? Who will protect 
you? So I use more of words not pictures, because of fear of the unknown. I streamline whatever I say on the social media. (Focus group discussion, 20 July 2013)

"Everybody is pro-joke, pro-entertainment, pro-fun..."; "I have this feeling that it's just us young people reading these things on Facebook and that we will just see the thing and it will just end there"; "I feel as if nobody will do anything, so I don't even bother myself to do anything more"; "In Nigeria, we are entertainment conscious; we really want things that could just excite us..."

Still on the reasons why it seems young people do not use Facebook for any social change agenda, such revealing ideological statements above are found to run through the discussions. Their capitulations range from the fact that:

1. They do not believe people will take them seriously. There is a feeling of hopelessness on the part of the young people. One of them said, "Even if you post such things that you think will be good for social change, somebody will be like "who told you", "na you sabi" (that's your business), "dis amebo sef (you are a busybody)"...They just think you are one of those people that like to bother themselves". This shows some youth even subject those who try to speak social change and social transformation, to ridicule.

2. There is a feeling that no one is interested in doing anything with what they have to say or agitate about. One participant opined "some people see Facebook as a voiceless voice, where you just keep talking and ranting and nothing is done about nothing".

3. There is a general pandering towards the more entertaining, fun and informal side of Facebook than the serious things. This gets some serious Facebook users among them, discouraged. One participant recounts rather bitterly "when you sit down and write reasonable things you want to share with others to start a reasonable conversation, you might just end up seeing only 1 comment but then you see someone else share a stupid joke, you could see like 500 hundred comments for that alone. So this gets you discouraged". Little wonder everyone agreed that young people on Facebook all seem to be pro-joke, pro-entertainment, and pro-fun. They posit that "in Nigeria, we are entertainment conscious; we really want things that could just excite us..."

4. Another reason for this situation among Facebook users in Nigeria could be what the participants have described as the fact of our being "at the receiving end of the new media revolution".

One of them had no hesitation in describing the situation thus:

In fact we are comfortable to be at the receiving end, you know. Everybody just wants to receive. This co-creation of contents we are talking about, it doesn't apply to Nigeria because we are always like "these things are already there, why should we bother ourselves?" And then we are almost everywhere on social media whereas people like us are the ones creating Twitter, 2go, Facebook, blogs and the rest. Nobody seems to be thinking of creating one; we just want to be there and receive. Once we hear of a new one, we just enter... (Focus group discussion, 20 July 2013). 
5. The attention span of people on social media such as Facebook is quite limiting. Hear one of the participants: "I think it's because people don't like things that sound serious; things that will take much of their time, they just need something that they can just take a quick glance at, something short, concise, straight-forward..."

Additionally, data from the survey suggest that majority of the respondents, even though aware of certain organisations on Facebook that champion social change, are not members of such organisations or groups. The points provided above might be used as justifying reasons why this is so. This therefore solves the puzzling observation earlier made in the quantitative analysis, on the reason why their level of awareness about such organisations/groups did not match their membership of such organisations. A few of the participants however mentioned some Groups they think champion using Facebook to bring about social change and transformation, but which they are not necessarily members of. They include: Abia State Awakening, Imo State Youth, Ndigbo, Nationalist Forum, One Love Keep Us Together, Feynolds Associates, Arise Network, Elites Visionaries' Congress, African Internet and Radio Biafra.

If these young people are doing little or nothing to critically engage the social media of Facebook in things that could bring about social change and transformation, it was important then to explore the kind of agenda they are consciously or unconsciously setting on Facebook. The participants allege that there appears to be a common feeling and attitude among young people that critical things such as social change, transformation and national development are not really for them. As one of them confesses:

Predominately, I think that we are setting the agenda that we don't amount to anything; that we are not part of the system. That we are not part of the decisionmakers in the country. So we often feel like we should leave the burden of thinking about the future to the leaders - those in the House of Assembly and in politics. Those are the ones who are thinking but oftentimes they are not thinking right. But we young people just feel like "let's just play, it's not our business". (Focus group discussion, 20 July 2013)

This speaks volume about their general attitude and disposition. This also suggests that these young people might be petrified, uncomfortable, unprepared, flippant or generally not confident in seeing themselves as change agents for their society. Perhaps this is why the respondents further allege that young people's agenda on Facebook smacks of frivolity, "just to waste time", "for lies and deceit". The overall kind of agenda which youths are using Facebook to set appears not to have any prospects of helping in any way to contribute to the so-called social transformation.

As a way to stimulate the young people whom I engaged in the focus group discussions, I attempted finding out what they thought is the inclusive role of youth in social and national development of Nigeria. Their responses are summarized below:

- Talking - The youths in the discussion believe that merely talking about our social and national needs in regards to development is one way youth can contribute. This talking could be online or offline as the case may be. They believe "our role is just to keep advising, to keep on talking. Even if they don't listen, I feel that if we keep saying it among us young people, we are changing our own orientation because many of us are ready to go and do worse things tomorrow". 
- Young people should start with themselves - looking inwards and changing attitudes and mind-sets that need changing and imbibing new, better ones.

- Being innovative and creative, according to them is another way young people can assert themselves in the society. This way, their contributions will speak for them.

- Aspiring to do greater things and not having a limiting mind-set about achieving goals and aspirations. The youth in the discussion believe that the first thing for the youth in Nigeria to do before worrying about contributing to social and national transformation is to become great and successful in their chosen careers and fields. They argue that the reason why it seems as though youth are not talking or not being heard is because they are still "no-bodies".

\section{Conclusion}

Vallor in 2007, before Facebook was officially made public in 2008, argued that people need to learn to cultivate certain 'virtues' that will help them realise the potential of socially and personally satisfying forms of communicative interaction online. In today's world of the Internet, digital technologies and the social media, as McDonnell (2011, p.6) would later point out, "it is the 'networked individual' who has to learn the skills and virtues that will make human flourishing possible in the hugely more complex communities of the online global polis".

In looking at the Nigerian youth that have been studied in this research, there is an apparent lack of these virtues as evangelised by the above authors. For technology and its inherent power not to become defeated in the future, it is important that critical questions about such technologies be asked and answered by this generation before diving into an uninformed use of such. Again, technologies should be studied in view of their inherent power and how such powers could be appropriately harnessed. What boyd (2010, p. 99) said about youth of this generation becomes relevant here:

By default, online we are nothing more than a series of bytes. In other to exist in any meaningful way, we must write ourselves into being. We must tell others who we are so that they can see us, so that they can interpret the signals that we give, as well as those we accidentally give off. This requires us to question who we are.

This questioning of "who we are" must entail Nigerian youth asking such questions as "what kind of a democracy are young people inheriting?", "what challenges face them as they acquire the rights and duties that come with democratic citizenship?" Perhaps this would be the first task any purposeful and determined-to-achieve-social-change Nigerian youth should take on. If he or she merely relies on the apparent and theoretical nuances of social media like Facebook, as having the power to give voice to the voiceless and powerless and creating a dialogic space or public sphere for young people and others to converge and fight for rights or cause revolutions such as was evidenced in Egypt, Tunisia, Moldova and Iran, then he or she might run into an illusion. From the careful review of literature, and the results of this study, it is now becoming clear that successful revolutions and change take more than the social media. It all boils down to the users of the social media themselves. Even the youth I engaged with in the focus group discussions agreed that before worrying about using social media in engendering social change and development, young people should not fail to keep talking to themselves and others about the need for a change; not failing to start with themselves - looking inwards and changing attitudes and mind-sets, and imbibing new and 
better ones; being innovative and creative - this way, they can easily assert themselves in the society. More so, they agree they ought to aspire to do great things; to first concern themselves with becoming successful in their chosen careers and fields today, so that when they talk tomorrow, people would be eager to listen as they would no longer be regarded as "no-bodies". Social media cannot give a user a power it has not consciously demanded from it. Social media do not bring about revolutions; it is people that do.

The talk of Twitter and Facebook revolutions is "a naive belief in the emancipatory nature of online communication that rests on a stubborn refusal to acknowledge its downside" (Morozov, 2010, p. xiii). Pointing, clicking, uploading, liking and befriending on Facebook would be "slacktivism" - "feel-good online activism that has zero political or social impact. It gives those who participate in 'slacktivist' campaigns an illusion of having a meaningful impact on the world without demanding anything more than joining a Facebook group" (Morozov, 2009). This is the reality of the use of social media for engendering a culture of social transformation by youth in Nigeria and even elsewhere. Studies have also affirmed that the so-called social media revolutions witnessed in Tunisia, Egypt, Libya, Moldova, Iran and the rest did not solely start online (Fuchs, 2014; Valenzuela, 2013; Safranek, 2012; Harlow, 2011). They point to the fact that there has to be first, an effort by some group to come together offline, develop strong ties and then move online to get more followers and to further use the social media for easier, faster and uncensored dissemination of critical information. Lovejoy \& Saxton (2012) were referring to this method when they shared that "by enacting individuals' offline networks online, social media can facilitate access to a large number of contacts, thereby enabling social movements to reach critical mass".

Indeed, the potentiality and dimensionality of Facebook and other social media regarding their enabling interactivity between people of various backgrounds, giving access to relevant information, as well as creation of a dialogic public space where citizens can congregate on common grounds to champion and engineer social transformation agenda for the society, cannot be denied. In this, the public sphere theory has proven very relevant and sustained. Though some of the postulations of the theory are increasingly being challenged by the inappropriate and disturbing uses-and-gratifications that young people derive from social media, arising from lack of critical knowledge, lack of a focused goal and conducive environment, yet, the power of social media cannot be easily ignored. Valenzuela (2013, p.922) further directs us to three main mediating mechanisms that explains why using social media can engender a collective action toward social change. First, social media is a veritable source for news, which this present study attests to; social media creates a space for political expression, and social media could be a tool for joining causes and finding mobilizing information. Indeed all hope is not lost, and as Johnson (2011, p.18) concludes, "the mere fact that nearly all youth use social networks shows that social movements would be foolish to ignore them". As one of the youth I engaged in focus group interview enthused, "Facebook is a market and [we] should try our best to utilize this market. It is a place where you don't need to know someone one-on-one to make an impact. You have a chance to impact a big crowd and Facebook is making it easier for us to get to that crowd" (Focus group discussion, 20 July 2013).

The case of Malala Yousafzai, a Pakistan 16-year old who at a young age started advocating for the rights of young girls in her community, thus represents a challenge for the $21^{\text {st }}$ century Nigerian youth. She was said to have defied the national order for "No education for girls" in Pakistan; was once shot in the head and left to die; but fortunately survived the attack and 
went on to use the blog she created as well as her articles in papers, to garner support for giving back the girl-child her rights in Pakistan. Today, she is reputed to have succeeded in sending many Pakistani girls back to school. One of my young discussants in the group discussion, challenged us all thus:

Today, 12 June has been named Malala Day by the United Nations; her birthday. Even before she addressed the UN, you can imagine that more than 3million young girls in UK signed to support her cause. Her father is not rich; he is just a school teacher/owner so if she can do what she did, then all of us in developing country of Nigeria can too. The problem is that we talk more on the Internet and do less on the outside world. Malala of course started with just a blog which she owns. She writes and sends to BBC, and they publish. (Focus group discussion, 20 July 2013).

As a democratic entity, Nigerian youth should not just be encouraged, but thus challenged to embrace online activism through the positive, prudent, informed, literate, and better appropriated use of the social media in their daily lives. This is not just a democratic clarion call, but a matter for urgent civic education, knowledge and enlightenment. 


\section{References}

Abubakar, A.A (2011) Political participation and discourse in social media during the 2011 Presidential Electioneering. Paper presented at the ACCE conference, Covenant University, Ota, September 2011.

Adaja, T.A. \& Ayodele, F.A. (2013). Nigerian youths and social media: Harnessing the potentials for academic excellence. Kuwait Chapter of Journal of Business \& Management Review 2(5), 65 - 75.

Ahn, J. (2011). The effects of Social networking sites on adolescents' social and academic development: Current theories and controversies. Journal of the American Society for Information Science \& Technology, 62(8), 1435 - 1445.

Allan, S. (2010). Issues in cultural and media studies. New York: McGraw-Hill.

Al-Jenaibi, B.N.A. (2011). Use of social media in the United Arab Emirates: An initial study. Global Media Journal, Arabian Edition, 1(2), 3 - 27.

Amadi, S. (2012). Nigerian youth, Nigerian failure, Nigerian hope. Text of lecture delivered at the 2012 International Youth Day Lecture organised by the African Centre for Media and Information Literacy (AFRICMIL) to mark the 2012 International Youth Day, Abuja, Wednesday, August 8, 2012.

Amaza, M. (2012). Are we done occupying Nigeria? Nigeria Dialogue online. Accessed 23 June 2013.

Asuni, J.B. \& Farris, J. (2011). Tracking social media: the social media tracking center and the 2011 Nigerian elections. Official document published by Shehu Musa Yar'Adua Foundation.

Boyd, d. (2010). Owning a digital identity. In C. Hannon \& C. Tims (Eds.), The anatomy of youth (pp. 94 -99). United Kingdom: Magdalen House.

boyd, d. m. \& Ellison, N. B. (2007) Social network sites: Definition, history, and scholarship. Journal of Computer-Mediated Communication, 13(1), 210 - 230.

British Council Nigeria (2012). Gender in Nigeria report 2012 ( $2^{\text {nd }}$ Edition). Published by the Department for International Development [UKaid].

Bruns, A. (2009, September). From prosumer to produser: Understanding user-led content creation. Paper presented at the Transforming Audiences Conference, London, UK. Retrieved from http://eprints.qut.edu.au/27370.

Chan-Meetoo, C. \& Rathacharen, D. (2010). Young adults and social networking sites in Mauritius. Published by the Faculty of Social Studies \& Humanities, University of Mauritius.

Chen, P.J. \& Vromen, A. (2012). Social media, youth participation and Australian elections. Document prepared by Australian Electoral Commission for the AEC Electoral Research Forum.

Constanza-Chock, S. (2012). Youth and social movements: Key lessons for allies. Published by Born This Way Foundation \& The Berkman Center for Internet and Society at Harvard University.

Dahlberg, L. (2011). Reconstructing digital democracy: an outline of four positions. New Media and Society, 13(6), 855-872.

Dhaha, I.S.Y. \& Igale, A.B. (2013). Facebook usage among Somali youth: A test of uses-andgratifications approach. International Journal of Humanities and Social Science, 3(3), $299-313$.

Dunu, I.V. \& Uzochukwu, C.E. (2011). Social media: an effective tool for social mobilisation in Nigeria. Being a paper presented at the Nwuneli International Conference on Communication, held 3 - 5 July 2011, BarnHill Hotel and Resort, Awka. 
Ebersole, S. (2000). Uses and gratifications of the web among students. Journal of ComputerMediated Communication, 6(1).

Ellison N., Steinfield C., Lampe C. (2007). The benefits of Facebook "Friends": Exploring the relationship between college students' use of online social networks and social capital. Journal of Computer-Mediated Communication 12(3), 1143-1168.

Evers, C. W., Albury, K., Byron, P. \& Crawford, K. (2013). Young people, social media, social network sites and sexual health communication in Australia: "This is Funny, You Should Watch It". International Journal of Communication 7, 263-280.

Facebook (2012b). Statistics. Available at: http://www.facebook.com/press/info.php?statistics Accessed 6 April 2013.

Fletcher, D. (2010, May, 31). Friends without borders. Time, $22-28$.

Fuchs, C. (2014). Social media - A critical introduction. London, California, New Delhi, Singapore: Sage.

Habermas, Jürgen. 1989. The structural transformation of the public sphere. Cambridge, MA: MIT Press.

Harlow, S. (2011). Social media and social movements: Facebook and an online Guatemalan justice movement that moved offline. New Media \& Society, 14(2), 225-243. DOI: $10.1177 / 1461444811410408$.

Hauben, M. \& Hauben, R. (1997). Netizens: On the history and impact of usenet and the Internet. Los Alamitos, Calif.: IEEE Computer Society Press.

Heaven, C. \& Tubridy, M. (2007). Global youth culture and youth identity. Available at http://www.verina.vesel.info/wp-content/uploads/2007/11/youth_culture1.pdf.

Johnson, M. (2011). Tweets from Birmingham jail. Media Development, LVIII (1), 17 - 18.

Kaplan, M. \& Haenlein, M. (2010). Users of the world, unite! The challenges and opportunities of social media. Business Horizons, 53 (1), 59 - 68.

Large, A. (2005). Children, teenagers, and the web. Annual Review of Information Science and Technology, 39(1), 347-392.

Liamputtong, P. (2010). Focus group methodology: Introduction and history. Cambridge University Press: Cambridge.

Lovejoy, K., \& Saxton, G. D. (2012). Information, community, and action: How non-profit organizations use social media. Journal of Computer-Mediated Communication, 17, 337-353. DOI:10.1111/j.1083-6101.2012.01576.x

Marichal, J. (2012). Facebook Democracy: The architecture of disclosure and the threat to public life, Surrey, UK, Ashgate.

Mayfield, T. (2008). What is social media? An e-book published by iCrossing, 4.

McDonnel, J. (2011). Only connect: Social relations in an online world. Media Development, LVIII (1), $3-6$.

Meerman Scott, D. (2010). The new rules of marketing and PR: How to use social media, blogs, news releases, online video, and viral marketing to reach buyers directly (2nd ed.). San Francisco: John Wiley and Sons.

Morozov, E. (2009). The brave new world of slacktivism. Foreign Policy. Retrieved from http://neteffect.foreignpolicy.com/posts/2009/05/19/the_brave_new_world_of_slackti vim

Morozov, E. (2010). The net delusion: How not to liberate the world. London: Allen Lane. Chapter 7: Why Kierkegard hates slacktivism.

My Media Generation (2005). Truly, madly, deeply engaged: Global youth, media and technology. Published by Yahoo! Summit Series. Available online. 
Nwonwu, F.C. (2 December, 2011). New media: Bridging the gap between government and the governed in Nigeria. Nigerian Village Square Online. Retrieved 28 March 2013.

Obijiofor, L. (2009). Perceptions and use of Internet and email technologies by Nigerian university undergraduate students. Paper presented at the African Council for Communication Education, ACCE conference, University of Ghana, Accra, 11 - 13 August 2009.

Omenugha, K.A, Ndolo, I.S. \& Uzuegbunam, C.E. (2012). Celebrity culture, media and the Nigerian youth: negotiating cultural identity in a globalised world. Paper presented at the International Association of Media and Communication Research (IAMCR) conference, Durban, South Africa, 15 - 19 July 2012.

Paxson, P. (2010) Mass communications and media studies: An introduction. New York: The Continuum International Publishing Group Ltd.

Policy Forum (2012). Engaging youth in planning education for social transformation. Provisional agenda from conference held 16 - 18 October 2012, IIEP, Paris, France.

Putnam, R. (2000). Bowling alone: The collapse and revival of American community. New York: Simon \& Schuster.

Safranek, R. (2012). The emerging role of social media in political and regime change. ProQuest. Available at http://www.csa.com/discoveryguides-main. Retrieved 21 January 2014.

Steinfield, C., Ellison, N. B., \& Lampe, C. (2008). Social capital, self-esteem, and use of online social network sites: A longitudinal analysis. Journal of Applied Developmental Psychology 29, 434-445.

Trusov, M, Bucklin, R. E, \& Pauwels, K. (2009). Effects of word-of-mouth versus traditional marketing: findings from an internet social networking site. Journal of Marketing 73, 90-102.

Ubayasiri, K. (2007). Internet and the public sphere: A glimpse of YouTube. Central Queensland University. Retrieved on June 30, 2013 from www.ejournalist.com.au/v6n2/ubayasiri622.pdf.

Ufuophu-biri, E. (2013). Perception and usage pattern of social media by students of higher institutions of learning in Delta State, Nigeria. Journal of Communication \& Media Research, 5(1), 15 - 26.

United Nations (2011). Youth participation in development. Summary guidelines for development partners. Available at www.ygproject.org. Accessed 26 February 2013.

Valenzuela, S. (2013). Unpacking the use of social media for protest behavior: The roles of information, opinion expression, and activism. American Behavioral Scientist 57(7), 920-942. DOI: 10.1177/0002764213479375.

Vallor, S. (2007). The present and future of social networking. Panel discussion at Santa Clara University.http://www.scu.edu/ethics/practicing/focusareas/technology/socialnetworking.html

Weinberg, T. (2009). The new community rules: Marketing on the social web. Sebastopol, CA: O'Reilly.

Wellman, B. \& Haythornthwaite, C. (Eds.) (2002). The Internet in everyday life. London: Blackwell.

$\mathrm{Wu}, \mathrm{J}$. (2009). An exploratory study of American youth's political engagement during the 2008 presidential election. Unpublished PhD thesis of the University of New York. 